\title{
Swiss-AlpArray temporary broadband seismic stations deployment and noise characterization
}

\author{
Irene Molinari $^{1}$, John Clinton ${ }^{2}$, Edi Kissling ${ }^{1}$, György Hetényi ${ }^{1,2, a}$, Domenico Giardini ${ }^{1}$, Josip Stipčević ${ }^{3}$, \\ Iva Dasović ${ }^{3}$, Marijan Herak ${ }^{3}$, Vesna Šipka ${ }^{4}$, Zoltán Wéber ${ }^{5}$, Zoltán Gráczer ${ }^{5}$, Stefano Solarino ${ }^{6}$, the \\ Swiss-AlpArray Field Team* , and the AlpArray Working Group ${ }^{* *}$ \\ ${ }^{1}$ Institute of Geophysics, Department of Earth Sciences, ETH Zürich, 8092 Zürich, Switzerland \\ ${ }^{2}$ Swiss Seismological Service, ETH Zürich, 8092 Zürich, Switzerland \\ ${ }^{3}$ Department of Geophysics, Faculty of Science, University of Zagreb, 10000 Zagreb, Croatia \\ ${ }^{4}$ Republic Hydrometeorological Service of Republic of Srpska, 7800 Banja Luka, Bosnia and Herzegovina \\ ${ }^{5}$ Kövesligethy Radó Seismological Observatory, Geodetic and Geophysical Research Institute of the \\ Hungarian Academy of Sciences, 1112 Budapest, Hungary \\ ${ }^{6}$ Istituto Nazionale di Geofisica e Vulcanologia, 00143 Roma, Italy \\ ${ }^{a}$ now at: Institute of Earth Sciences, University of Lausanne, 1015 Lausanne, Switzerland \\ *A full list of authors and their affiliations appears at the end of the paper. \\ ** www.alparray.ethz.ch
}

Correspondence to: Irene Molinari (irene.molinari@erdw.ethz.ch)

Received: 24 July 2016 - Revised: 6 September 2016 - Accepted: 23 September 2016 - Published: 12 October 2016

\begin{abstract}
AlpArray is a large collaborative seismological project in Europe that includes more than 50 research institutes and seismological observatories. At the heart of the project is the collection of top-quality seismological data from a dense network of broadband temporary seismic stations, in compliment to the existing permanent networks, that ensures a homogeneous station coverage of the greater Alpine region. This Alp Array Seismic Network (AASN) began operation in January 2016 and will have a duration of at least 2 years. In this work we report the Swiss contribution to the AASN, we concentrate on the site selection process, our methods for stations installation, data quality and data management. We deployed 27 temporary broadband stations equipped with STS-2 and Trillium Compact 120 s sensors.

The deployment and maintenance of the temporary stations across 5 countries is managed by ETH Zurich and it is the result of a fruitful collaboration between five institutes in Europe.
\end{abstract}

\section{Introduction}

In order to gain a deep understanding of the solid Earth system, including fields as diverse as seismotectonics, lithosphere structure, geodynamics and earthquake hazard, highquality seismic data from dense networks are a pre-requisite. It is increasingly common to deploy large-scale temporary seismic experiments that complement existing permanent seismic stations and improve the spatial resolution of scientific studies. Recent and well-known examples of major scientific projects that target improved resolution using temporary seismic networks are the USArray (www.usarray. org), IberArray (iberarray.ictja.csic.es; Díaz et al., 2010) and the on-going AlpArray project (www.alparray.ethz.ch). The main scientific goals drive the network geometry, instruments and installation choices. All these projects require, as a standard, excellent data quality across a broad frequency range: from short periods that target local seismicity and shallow structure, to long periods $(T>100 \mathrm{~s})$ required for deep Earth studies. The quality of the seismic stations - determined by site selection, hardware and installation techniques - is therefore crucial for a successful project. In these projects, each individual site should allow low-noise at both short and long periods. Avoiding anthropogenic noise sources such as roads, 
railway lines, inhabited areas in general, industrial plants, as well as rivers, will keep the high-frequency noise at a low level. At long periods, selecting sites that minimise temperature and pressure changes and avoid long-period ground tilt, lead to improved low-frequency performances.

While selecting sites for permanent broadband stations usually includes a long, careful and expensive site search, noise tests and vault construction, in a temporary deployment one has to find a good compromise between time, budget, feasibility and project requirements in terms of network geometry and data quality.

In this work we describe the Swiss contribution in the AlpArray Seismic Network in terms of the existing permanent stations, site selections and installations of temporary stations, data quality and data management. The deployment and maintenance of the 27 Swiss temporary broadband stations is led by ETH Zurich (Seismology and Geodynamics group, SEG, and the Swiss Seismological Service, SED). These stations are a product of a fruitful collaboration between five institutes in Europe, supported by funding from the Swiss-AlpArray SINERGIA program of the Swiss National Science Foundation.

\section{AlpArray initiative and seismic network requirements}

AlpArray (http://www.alparray.ethz.ch) is a European initiative to advance our understanding of orogenesis and its relationship to mantle dynamics, slabs properties, surface processes, and seismic hazard in the Alps-ApenninesCarpathians-Dinarides orogenic system. One of the main objectives of the project is to integrate present-day Earth observables with high-resolution geophysical imaging techniques (local earthquake tomography, surface wave tomography from ambient noise, full waveform tomography, receiver functions, anisotropy studies) to obtain detailed 3-D anisotropic structure of the lithosphere and upper mantle. In addition, a uniform, highly consistent local earthquake catalogue and a detailed study of the local and regional seismicity will be a fundamental part of the project, being a prerequisite to improve seismotectonic knowledge of the greater Alpine region and earthquake hazard assessment. The AlpArray (AA) scientific programme involves a large number of researchers from countries around the world. Up to now, 45 institutes from 18 countries have joined AA. The project is organized in working groups (Procedures and data managements, AlpArray seismic network operations, Research and interpretation, as well as Outreach and education), research groups (e.g. surface wave and full waveform tomography, local earthquake tomography, seismic catalogue, gravity) and collaborative projects to enhance new ideas, collaborations and to develop new methods for a deeper 3-D understanding of the mountain building processes that shaped the Alpine orogen.
The AlpArray science plan relies on the collection of high-quality seismological data from a dense network of broadband temporary seismic stations, that, in addition to the permanent broadband networks, ensures homogeneous coverage of the Alpine area, with station spacing of $\sim 40 \mathrm{~km}$ (Fig. 1). At present, the AlpArray Seismic Network (AASN) includes 24 actively participating institutions (http://www.alparray.ethz.ch/seismic network/backbone/management/) with $\sim 390$ permanent and $\sim 260$ temporary broadband stations installed in 10 countries. The official starting time of AASN operation was 1 January 2016 and it will operate for at least 2 years. To be part of the AASN Seismic Network, each station (temporary and permanent) has to satisfy high-quality standards (see AA technical strategy, www.alparray.ethz.ch/organisation/ documents/). Meeting these standards is a key requirement to guarantee success of such an international project, especially since the participating temporary seismic stations consist of diverse instrumentation types.

It is important to mention the main deployment rules that constrain the site selection for the temporary broadband station. To ensure a proper spatial coverage, every AlpArray temporary station should be within a $3 \mathrm{~km}$ radius from the initially proposed locations. Deviations up to a $6 \mathrm{~km}$ radius are allowed for specific reasons and only after approval of the AlpArray Seismic Network managers. No strict technical specification is given for the installation and vault setup. Rather, mandatory guidelines concerning the site-noise level must be satisfied. The allowed site-noise levels for all 3 components are defined using PSDs typically computed using PQLX (McNamara and Boaz, 2005). The median value for the noise should be $20 \mathrm{~dB}$ lower than the New High Noise Model (NHNM) (Peterson, 1993) from $20 \mathrm{~Hz}$ up to $100 \mathrm{~s}$, excluding the microseismic peak (5-20s) The only exception is made for the long period ( $20-100 \mathrm{~s}$ ) horizontal components for which the noise level can be up to $10 \mathrm{~dB}$ lower then NHNM, to account for noise associated with temperature and pressure fluctuations that introduce ground tilt, which is difficult to avoid in temporary deployments. There are additional requirements placed on the deployed hardware. Each seismic sensor must have 3 components and be broadband with a flat velocity-response in the frequency domain from at least 0.03 to $20 \mathrm{~Hz}$, preferably down to $0.008 \mathrm{~Hz}$. Digitisers must be $>130 \mathrm{~dB}$ between 0.1 and $10 \mathrm{~Hz}$ and all data must be recorded with 100 sps or higher sampling rate. The data have to be provided to an EIDA node in miniSEED format preferably in near-real time, but in the absence of real-time communications data should be retrieved with a latency of maximum 3 months. Real-time data streaming or station health information is highly recommended to ensure a timely checking of the station performance. In the long term, this has a better cost/result ratio than an off-line site. All AASN station operators should be capable of providing correct dataless SEED information. 


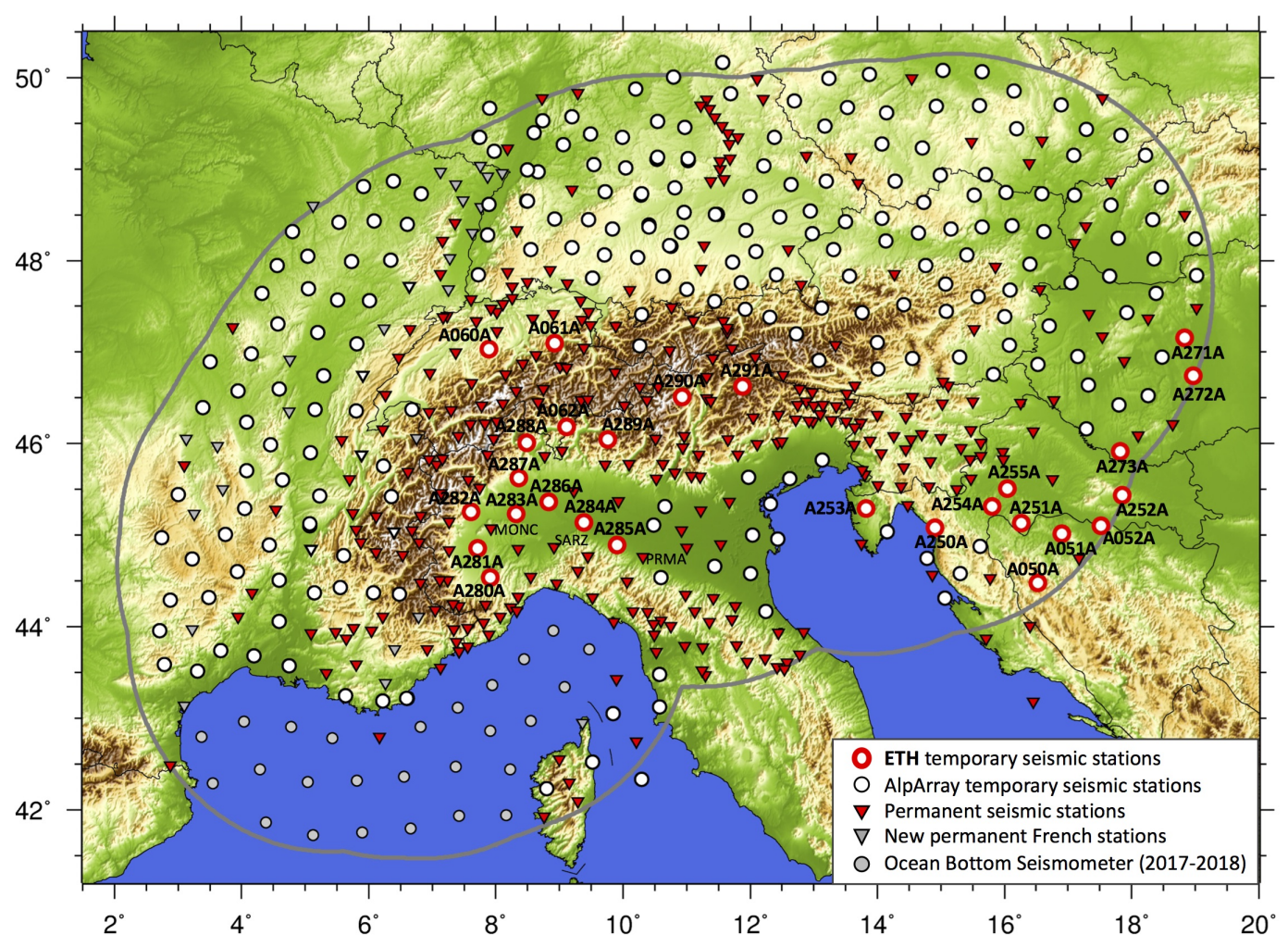

Figure 1. Map of the AlpArray broadband seismic stations, with the permanent stations (red inverted triangles), the new permanent French stations (grey inverted triangles) for which the installation is expected during the AlpArray project, the AlpArray temporary stations (white circles) and the Ocean Bottom Seismometer plan (grey circles). The Swiss installations are marked with red circles, labelled with the station name. The grey line marks the AlpArray boundary. MONC, SARZ and PRMA are three permanent INGV stations discussed in Fig. 6.

Here we describe our temporary station concept and site selection scheme used for the Swiss station deployed that allow us to reach the AASN quality criteria and to provide high quality seismic data to the AlpArray project.

\section{Swiss contributions in the AlpArray Seismic Network}

\subsection{Network geometry and infrastructural setting}

The Swiss-AlpArray SINERGIA project covers the cost for deployment and operation for 2 to 3 years of $\sim 30$ temporary stations from the SED/SEG mobile seismic station pool. Considering the objective of a uniform station coverage in the greater Alpine area and the total number of available temporary stations among the partners, the AASN managing group has assigned to our institute the deployment of 27 stations: 3 in Switzerland, 12 in Italy, 6 in Croatia, 3 in Bosnia and Herzegovina and 3 in Hungary (Fig. 1). The installation of temporary stations in five nations has only been possible thanks to the fruitful collaboration between ETH Zurich $(\mathrm{CH})$ and the AlpArray local partners - University of Zagreb (HR), Republic Hydrometeorological Service of Re- public of Srpska (BiH), Geodetic and Geophysical Research Institute of the Hungarian Academy of Science (HU) and Istituto Nazionale di Geofisica e Vulcanologia (IT). Together we shared planning, best practice and used common guidelines for site search and station installation.

The large scale morphology and geology of the 27 sites are diverse: 8 are located within or on the hilly border of the Po Plain basin; 4 are within or in the hilly part of the Pannonian basin, 2 are in the Sava and Kupa valleys, and 13 are on mountainous terrain (Swiss Alps, Dolomites, and Dinarides). While there are many parts of the AlpArray area that can be considered challenging regions for finding low-noise sites for seismic stations, the large and deep sedimentary basins of the Po Plain, Molasse and Pannonian basin are some of the most challenging targets for the AASN due to high population and infrastructure density. In the Dinarides, an unusual constraint on site selection was personal safety, in particular avoiding minefields.

\subsection{Station design}

A Swiss temporary seismic station in AASN consists of the following components (Fig. 2): STS-2 (120s) or Trillium 
(a)

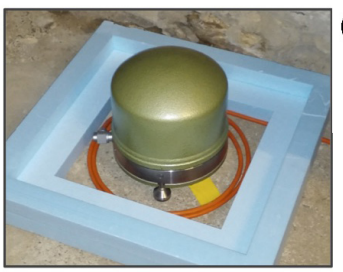

(e)

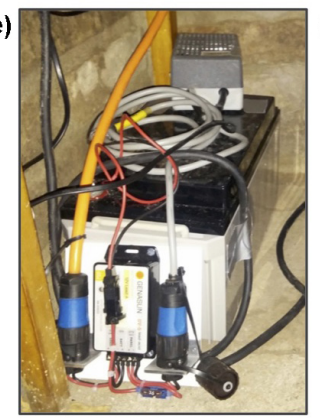

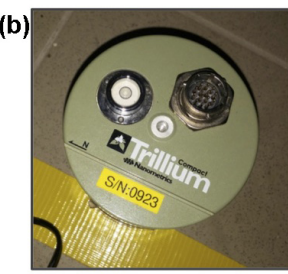

(f)

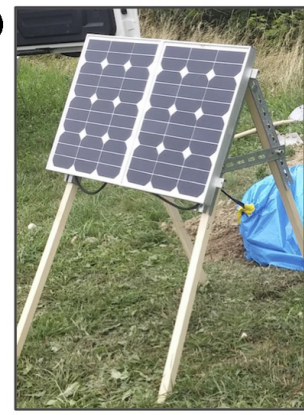

(c)

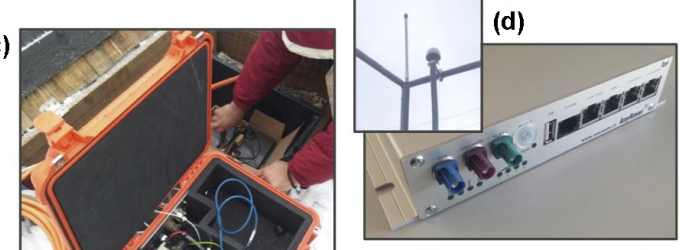

(g)

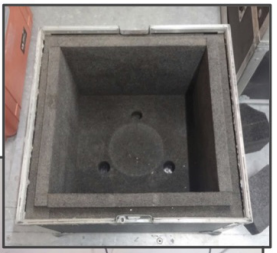

(h)

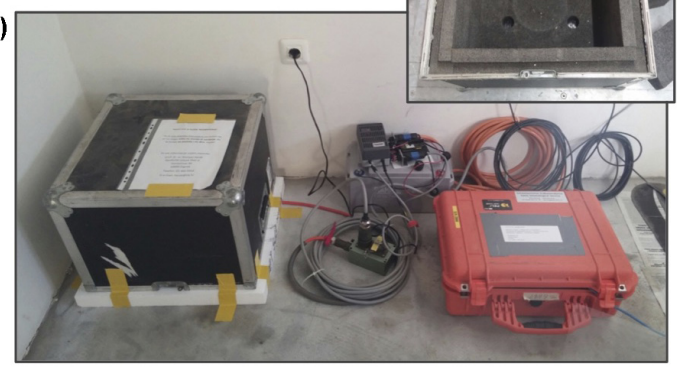

Figure 2. Components of an ETH temporary station. (a) STS-2 sensor, (b) Trillium Compact 120 s sensor, (c) Taurus digitizer, (d) Router (AnyRover), GPS and GPRS antenna, (e) battery, (f) solar panel, (g) thermal isolation, (h) typical final in-house station configuration with all the components.

Compact $120 \mathrm{~s}$ sensor (Fig. 2a, b), Taurus 3-channel 24 bit digitizer (Fig. 2c) with $>141 \mathrm{~dB}$ dynamic range (100 sps sampling rate), GPS antenna, AnyRover mobile access router (Dual-Modem High-speed LTE and WLAN Router) for realtime data communication, mobile antenna 4G-LTE (Fig. 2d) and 65Ah battery (Fig. 2e). In those sites where mains power supply is not available, the station is powered by 2 solar panels with $30 \mathrm{~W}$ peak power, $17.6 \mathrm{~V}$ voltage and $1.68 \mathrm{~A}$ current each (Fig. 2f). All stations always support real-time data stream, expect at the handful of sites powered by solar, where in order to save energy, the data is transferred daily only in a single $2 \mathrm{~h}$ window (quasi-real time communication). The router can be remotely controlled, rebooted, turned on and off via SMS (Short Message Service). In addition to the real-time streaming to SED-ETH servers in Zurich, the data is also stored locally on a 16 or 24 GB flash cards. With our configuration, a real-time streaming station power rating is $\sim 8 \mathrm{~W}$ while it decreases to $\sim 3-4 \mathrm{~W}$ when the router is turned off. Without a power source other than the battery a station can survive for some days in communication mode, and for more than a week without communication.

We use a water-proof "PeliCase" with all the necessary connectors to protect and to thermally isolate the digitizer and the router (Fig. 2c, h). Thermal isolation for the sensor (especially important for the STS-2) is ensured, for inhouse installations ( 23 sites), by a $5 \mathrm{~cm}$ thick box made of polystyrene and wood that is also used for STS-2 transportation (Fig. 2g), on top of a polystyrene frame. In many sites, we cover this box with a rescue blanket (see Fig. 3h) to provide further protection from direct sunlight. The sensor is usually placed on cement, in the ground floor of small houses. In presence of tiles, we preferably remove them or we make sure they are well connected with the cement-floor base.

4 sensor are deployed in buried hand-dug vaults. Our prototype vault consists of a buried, waterproof, bottomless barrel inserted into an up to $20 \mathrm{~cm}$ of cement plate. In one case, we had to build a drainage channel to avoid standing water around and inside the barrel. In these cases, the station hardware is identical to other sites and the sensor is thermally isolated with mineral wool and flexible polystyrene panels. For the AlpArray project, we deployed 24 STS-2 and 3 Trillium Compact $120 \mathrm{~s}$.

\subsection{Site search}

When selecting the optimal site for a seismic station, there is always a compromise between the available budget and manpower, local and regional geology and land use, and available hardware. There are well-established general field procedures and rules for site search (e.g. http://www.passcal.nmt.edu/content/ instrumentation/field-procedures-3; Forbriger, 2012) that have to be interpreted in the light of the particular seismic experiment. In general, better noise levels are achieved when the sensor is buried or when it is directly placed on stable bedrock such as in a cave. In open land, it is recommended to build seismic vaults. For our project, we note that there are important caveats to these general rules - in particular, the noise improvement from burial is not always significant, 
especially where there are soft and deep sedimentary layers and where the bedrock is buried beneath several $\mathrm{km}$ of sediments - an prime example is the Po Plain. In these cases small, one-story buildings with solid foundations are likely to provide similar noise levels as isolated vaults. Moreover, building a vault is usually expensive, time consuming and it is sometimes difficult to ensure that it remains dry even in normal conditions when the water table is close to the surface or flooding is expected. As a general rule for AlpArray we consider building seismic vaults only where secure and potentially promising sites were impossible to find elsewhere. We avoid using vaults in the sedimentary basins because the risk of floods is usually too high.

For the AlpArray project we based our site scouting on the following general principles:

Network geometry: We follow the agreed 3 resp. $6 \mathrm{~km}$ rule described above. We were forced to go beyond the $3 \mathrm{~km}$ radius on a few occasions where the initial targeted position was in the middle of inaccessible mountains (A288A, with no possibility to reach the station during winter time) or in the middle of a large city (A285A, Fiorenzuola D'Arda, Italy, where the high-speed train line and a highway are close-by throughout the $3 \mathrm{~km}$ radius) and in some sites in Bosnia and Herzegovina as well as Croatia where terrain morphology or accessibility did not allow safe site access.

Off-site studies: Much of the site scouting can be accomplished from the office. From a first web search including google maps a set of plausible sites are selected, then possible owners and local and regional authorities are contacted. Communicating with local authorities about seismic site requirements is a very important step: their deep knowledge of the area, especially concerning land ownership, allows quick rejection of many potential sites, and to rapid permissioning for installation. Even in advance of a site visit, it is possible to have an idea of the suitability of the site in terms of accessibility, safety, and resources - power, communications, sky visibility for GPS. However, a site visit for inspection before the final installation is mandatory. We always check the geological condition of the potentials sites, preferring rocky sites with low slope. All this work minimizes upcoming fieldwork efforts and their associated costs.

Permission, accessibility and safety: Normally, sites should be accessible by car (or within half an hour walking distance) year-round, in all reasonable weather conditions. The instruments should not be exposed to risk of flood, vandalism and other potential damage. For safety, we prefer indoor sites that can be locked or sites not easily accessible by the general public.

Seismic noise evaluation: We search for sites that are as distant as possible from any human activity, such as towns, industry, constructions, transportation, pipelines, electrical lines, mines, agriculture, rivers, tidal areas, trees, etc. Nowadays, especially in the Po Plain and in the Pannonian basin, but also in very busy mountain valleys (Dolomites) it can be practically impossible to find surface sites far from an- thropogenic noise sources. If a building is seing selected, it cannot be actively used by people or animals, or have active heating systems, water pumps, or any other kind of noisy devices. We generally seek to maintain a minimum of $3-4 \mathrm{~km}$ distance from railroads, $2-3 \mathrm{~km}$ from major highways, and $100-500 \mathrm{~m}$ from small local roads. Avoiding these kinds of noise sources significantly improves the likelihood of meeting the high-frequency noise requirements. For the broadband sensors used in AlpArray, long-period performance is susceptible to noise arising from temperature and pressure instabilities, a poorly levelled sensor, and horizontal tilt of the sensor mainly due to vehicular traffic, trains and people that affect the building (or vault) in which the sensor is installed. To reach the low-frequency noise requirements (median PSD noise level at or below $20 \mathrm{~dB}$ less than the NHNM for the vertical component and $10 \mathrm{~dB}$ less for the horizontal) we consider sites in small, one-story buildings with cement floor and far away from possible persistent traffic of people $(50 \mathrm{~m})$ and cars $(1-2 \mathrm{~km})$. Small, stiff buildings are preferred to larger ones because their natural frequencies do not interfere with the frequency range of interest $(0.009-10 \mathrm{~Hz})$ for most scientific purposes. It is well known that an appropriate thermal insulation of the sensor strongly improves the noise level at long periods on all components (e.g. Langlais et al., 2013), and sensors are always insulated (Fig. 2). Preinstallation noise tests at plausible sites can strongly help in assessing the quality of a site and in avoiding unpleasant surprises. At certain sites, when the agreed noise level was exceeded, the station was moved to a quieter site (an example is the A283A station, see Sect. 3.4).

Connectivity and data transmission: one of our main goals is to have real-time data transmission, so that the stations can be used for alerting purposes, but also for station health verification. Knowing whether a station is working can prevent unnecessary site visits, and optimise station up-time as problems are immediately recognised. Our router device supports the use of standard mobile SIM-cards with data traffic, hence our candidate sites should have a good and stable mobile network coverage. The minimum requirement is a sufficient signal strength and stability to transmit state-ofhealth data, though preferably continuous $100 \mathrm{sps}$ waveform streams should be transmitted as well. This condition has forced us to discard some potentially good sites, especially in remote mountainous areas.

The GPS signal should be checked and the antenna has to be able to regularly lock onto at least 3-4 satellites to guarantee correct timing and coordinates.

Power supply: In principle our autonomous offline station setup can stay powered, even throughout the Alpine winter, with $2(30 \mathrm{~W})$ solar panels. Nevertheless, the real-time communication requirement forces us to prefer sites with regular $50 \mathrm{~Hz} / 230 \mathrm{~V}$ power grid. For sites with no mains power, we apply a hybrid solution with quasi-real time communication (see Sect. 3.2). A promising site without mains power (i.e., where solar panels are needed) is thus a feasible solution. 

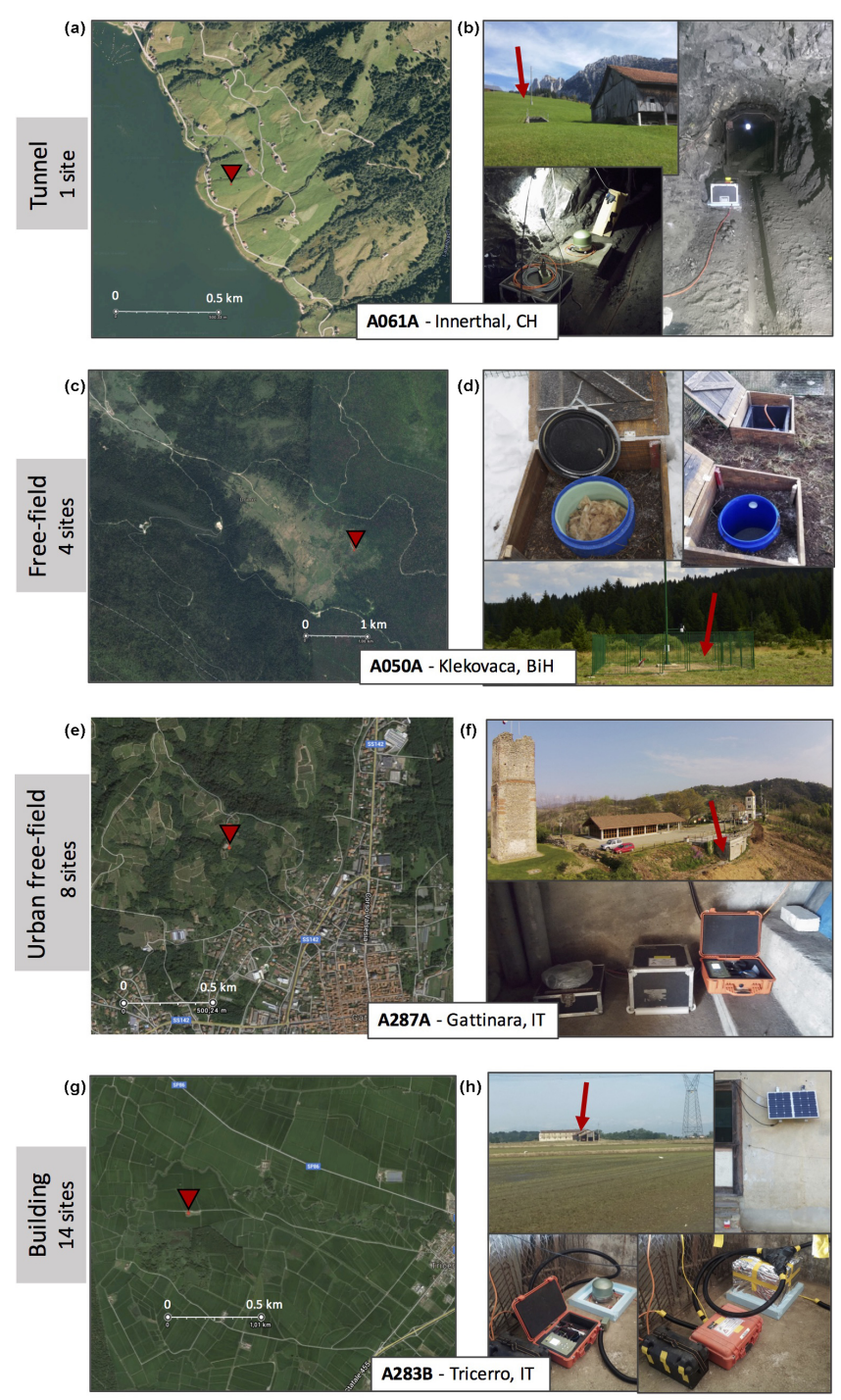

Figure 3. Examples of site location and installation configurations for four housing types (rows). In the first column we show the station position on Google Earth (red triangles) and, in the second column, pictures from each installation. One of these picture shows an overview of the site and a red arrow approximately indicates the sensor locations. The stations are: (a) and (b) A061A in Innerthal, Switzerland; (c) and (d) A050A in Klekovača, Bosnia and Herzegovina; (e) and (f) A287A in Gattinara, Italy; (g) and (h) A283B in Tricerro, Italy.

Our final site selection normally falls on those sites that have optimal balance between all the above requirements and principles. Typically, our preferred site is in a small, onestory, uninhabited building with mains power and GSM coverage. Noise tests are performed in most of the sites. However, in some cases, we directly install the stations in the potentially best site (after different site inspections), with the possibility to move the station if the performance is not satisfactory.

\subsection{Installations and final stations configuration}

The installation of our 27 stations began in September 2015 in Switzerland and in Italy, followed by Bosnia and Herzegovina, Croatia and Hungary. By the official start-date of the project on 1 January 2016, 21 of our stations were operational. The last 3 stations were installed in Croatia in early June 2016. An overview of their basic characteristics are listed in Table 1. Our typical installation in a building takes 3-4 h, while a free-field installation needs 2 days of work by two experienced persons.

Overall, our installations comprise 4 vaults sites and 23 stations installed in small buildings or houses. Only 3 stations are powered by solar panels with data transmission in quasi-real-time, the rest have mains power and transmit the data in real time to the ETH EIDA node (see Sect. 4.1). According to the internal sensor housing descriptions as defined by SED and used for the AlpArray project, we have four sensor housing types in our temporary station set: tunnel (1), free-field (4), urban free-field (8) and building (14).

The only station installed in a tunnel is station A061A (Fig. 3a). A tunnel is defined by the SED as man-made subterranean gallery typically with cylindrical shape with diameter between $1-10 \mathrm{~m}$ allowing human passage. The sensor is placed on a cement base $60 \times 60 \times 30 \mathrm{~cm}^{3}$ at the end of the $100 \mathrm{~m}$ long tunnel (Fig. 3b) built for water drainage and for strain measurements. The GPS and GPRS antennae are placed outside the tunnel using low-loss coaxial cables, with mains power from a nearby house.

In a free-field station the sensor is defined to be located less than $5 \mathrm{~m}$ below surface and farther than one times the height of the surrounding structures. One example is the station A050A in Klekovača, Bosnia and Herzegovina (Fig. 3c) on a bare hill in the middle of a forest. We built two vaults, one for the sensor with a plastic pot with a $20 \mathrm{~cm}$ high cement base, and one to host the digitizer, cables and the battery (Fig. 3d). No standing water is expected in that area and the site has slight slope to avoid any possible flooding. The site is inside a meteorological observation station that is fenced and secured.

When sensors are located less than $5 \mathrm{~m}$ below surface and within one times the height of the surrounding structures but inside a small 1-story building, we define the housing type as urban free-field. The station A287A in Gattinara (Italy) is an example (Fig. 3e). The sensor is in the ground floor of a largely buried one-story concrete structure with a flat roof rarely used for parking cars. The building is isolated on the hilltop near an old church and tower. The surrounding area is densely covered with vineyards. The sensor is on an exposed hill edge with steep slope below and placed directly on concrete (Fig. 3f). There is mains power and a very good mobile GPRS signal.

If sensors are located inside the basement of a more than one-story building, the housing type is labelled building. Most of our installations are inside remote small buildings 
Table 1. List of the Swiss-AlpArray installed between September 2015 and June 2016, with station name, coordinates, start and end time, type of housing, sensor ( $\mathrm{TC}=$ Trillium Compact $120 \mathrm{~s}$ ) and country of deployment. The network code is $\mathrm{Z} 3$ for all the stations.

\begin{tabular}{|c|c|c|c|c|c|c|c|c|c|c|}
\hline $\begin{array}{l}\text { Station } \\
\text { Name }\end{array}$ & Lat & Lon & $\begin{array}{r}\text { Elev } \\
(\mathrm{m})\end{array}$ & Site Name & $\begin{array}{l}\text { StartTime } \\
\text { (yyyy-mm-ddThh:mm:ss) }\end{array}$ & $\begin{array}{l}\text { EndTime } \\
\text { (yyyy-mm-ddThh:mm:ss) }\end{array}$ & Country & Housing Class & $\begin{array}{l}\text { Sensor } \\
\text { sits on }\end{array}$ & $\begin{array}{l}\text { Sensor } \\
\text { type }\end{array}$ \\
\hline $\mathrm{A} 050 \mathrm{~A}$ & 44.4818 & 16.5313 & 934 & Klekovača & 2015-11-25T15:30:00 & - & $\mathrm{BiH}$ & Free-field & cement & STS-2 \\
\hline A051A & 45.0125 & 16.9069 & 862 & Vila Mrakovica & 2015-11-25T15:00:00 & - & $\mathrm{BiH}$ & Building & cement & STS-2 \\
\hline A052A & 45.1026 & 17.5139 & 139 & Srbac & 2015-11-26T17:00:00 & - & $\mathrm{BiH}$ & Free-field & cement & STS-2 \\
\hline A060A & 47.0305 & 7.8904 & 1161 & Wasen, Napf & 2015-08-14T14:00:00 & - & $\mathrm{CH}$ & Free-field & cement & STS-2 \\
\hline A061A & 47.098 & 8.9252 & 961 & Innerthal, SZ & 2015-10-14T16:00:00 & - & $\mathrm{CH}$ & Tunnel & cement & STS-2 \\
\hline A062A & 46.1808 & 9.1126 & 1783 & Arbedo Castione & 2015-11-17T15:00:00 & - & $\mathrm{CH}$ & Building & cement & STS-2 \\
\hline A250A & 45.084 & 14.9106 & 686 & Rusevo Krmpotsko & 2015-11-29T14:30:00 & - & HR & Building & cement & STS-2 \\
\hline A251A & 45.1286 & 16.2664 & 252 & Rujevac & 2015-11-30T12:30:00 & - & HR & Building & cement & STS-2 \\
\hline A252A & 45.4356 & 17.8482 & 412 & Venje & 2015-11-27T14:30:00 & - & HR & Building & cement & STS-2 \\
\hline A253A & 45.2926 & 13.8167 & 408 & Karojba - Istria & 2016-06-06Т16:00:00 & - & HR & Building & tiles & STS-2 \\
\hline A254A & 45.3148 & 15.805 & 543 & Petrova Gora & 2016-06-07T13:30:00 & - & HR & Building & cement & STS-2 \\
\hline A255A & 45.509 & 16.0507 & 224 & Vukomeričke gorice & 2016-06-07T18:00:00 & - & HR & Building & cement & STS-2 \\
\hline A271A & 47.1547 & 18.8341 & 165 & Iváncsa & 2016-01-13Т11:30:00 & - & $\mathrm{HU}$ & Urban free field & tiles & $\mathrm{TC}$ \\
\hline A272A & 46.7444 & 18.9654 & 170 & Bölcske & 2016-01-13T15:00:00 & - & $\mathrm{HU}$ & Building & tiles & $\mathrm{TC}$ \\
\hline A273A & 45.9163 & 17.8161 & 100 & Marócsa & 2016-03-02T13:00:00 & - & $\mathrm{HU}$ & Building & tiles & $\mathrm{TC}$ \\
\hline A280A & 44.5391 & 7.9089 & 288 & Farigliano, Viaiano & 2015-09-15T16:50:00 & - & IT & Urban free field & cement & STS-2 \\
\hline A281A & 44.8534 & 7.7099 & 292 & Carmagnola & 2015-09-16T00:00:00 & - & IT & Urban free field & cement & STS-2 \\
\hline A282A & 45.2545 & 7.6133 & 428 & San Carlo Canavese & 2015-09-16T17:00:00 & - & IT & Urban free field & tiles & STS-2 \\
\hline A283A & 45.2296 & 8.3208 & 185 & Tricerro & 2015-09-17T12:00:00 & 2016-03-17Т09:00:00 & IT & Urban free field & cement & STS-2 \\
\hline A283B & 45.238 & 8.2885 & 195 & Tricerro & 2016-03-17T16:00:00 & - & IT & Building & cement & STS-2 \\
\hline A284A & 45.1371 & 9.3837 & 99 & Costa De Nobili, Padulino & 2015-09-20T18:00:00 & - & IT & Urban free field & cement & STS-2 \\
\hline A285A & 44.8939 & 9.9098 & 152 & Lusurasco & 2015-09-16T17:00:00 & - & IT & Urban free field & tiles & STS-2 \\
\hline A286A & 45.366 & 8.8338 & 170 & Villa Reale - Cassolnovo & 2015-09-07T16:00:00 & - & IT & Urban free field & cement & STS-2 \\
\hline A287A & 45.6225 & 8.361 & 423 & Gattinara, La Torre & 2015-09-07T16:00:00 & - & IT & Urban free field & cement & STS-2 \\
\hline A288A & 46.0082 & 8.4818 & 1306 & Cicogna & 2015-09-06Т16:00:00 & - & IT & Free-field & cement & STS-2 \\
\hline A289A & 46.0473 & 9.761 & 1780 & Foppolo & 2015-09-09Т16:00:00 & - & IT & Building & cement & STS-2 \\
\hline A290A & 46.5068 & 10.928 & 1729 & San Nicolo, Ultimo & 2015-11-12Т18:30:00 & - & IT & Building & cement & STS-2 \\
\hline A291A & 46.6246 & 11.8805 & 1568 & Badia & 2015-09-22T17:00:00 & - & IT & Building & cement & STS-2 \\
\hline
\end{tabular}

where power and mobile coverage were available. The station in Tricerro (Italy) in the Po Plain is an example. The area is intensely cultivated with rice (dense network of water channels and water pumps) and the typical surface terrain is mostly clay and loose sediment. Our first attempt has been the installation of station A283A. The noise level was too high so the station was moved to a new location $1 \mathrm{~km}$ away in March 2016. The new station is A283B (Fig. 3g, h) for which the noise levels are more appropriate. The sensor is in a large two-story building, placed directly on concrete. In the whole Po Plain buried cellars are rare because of flood problems. Here we installed solar panels and we protected all the cables from rats (Fig. 3h).

All the sensors are thermally insulated and all the installations are secured following the best practises for installations of (permanent) broadband sensors, STS-2 in particular (e.g. Hutt and Ringler, 2009). The sensor orientation is carefully determined using a compass. However, we are aware of possible errors due to unexpected local disturbance of the magnetic field, especially in buildings and urban areas in general. We plan, in the near future, to verify sensor orientation using teleseismic events (Ekström and Busby, 2008) and to perform careful final orientation of the sensors with a gyrocompass.

The performances in terms of noise levels of the above mentioned example stations are described in the next section. A complete list of all the AlpArray temporary installations can be found in the ORFEUS Station Book (www.orfeus-eu. org/stationbook).

\section{Network performances}

After data acquisition, an automatic procedure run nightly calculates the distribution of seismic power spectral density (PSD) using the direct Fourier method (Cooley and Tukey, 1965), using the PQLX software package based on McNamara and Buland (2004). These probability density functions (PDFs) of the PSD allow us to identify the ambient noise conditions as high probability occurrences and it is nowadays a standard tool to examine artefacts related to station operation, episodic cultural noise, the overall station quality and the level of Earth noise at each site. The daily updates of the PSDs for the Swiss-AlpArray stations are available at http://www.seismo.ethz.ch/research/groups/alrt/ products/pqlx/pqlx_images_z3. The quality of our temporary installations strongly depends on the region in which the site is located. A summary of the PSD medians, separated for sites in sedimentary basins and sites in the mountains, in comparison with the NHNM and the AlpArray Seismic Network requirements is shown in Fig. 4. Generally, our temporary installations show an ambient noise below the NHNM level for all frequencies. Stations in the Po Plain basin and in the Pannonian basin show, as expected, higher noise levels for shorter periods $(T<1 \mathrm{~s})$ than stations in the Alps and Dinarides (Fig. 4a, c). Intermediate periods are dominated by the primary and the secondary microseismic peaks and the amplitudes are again higher in the basin sites. Vertical longperiod noise is quite low (lower than the maximum allowable 

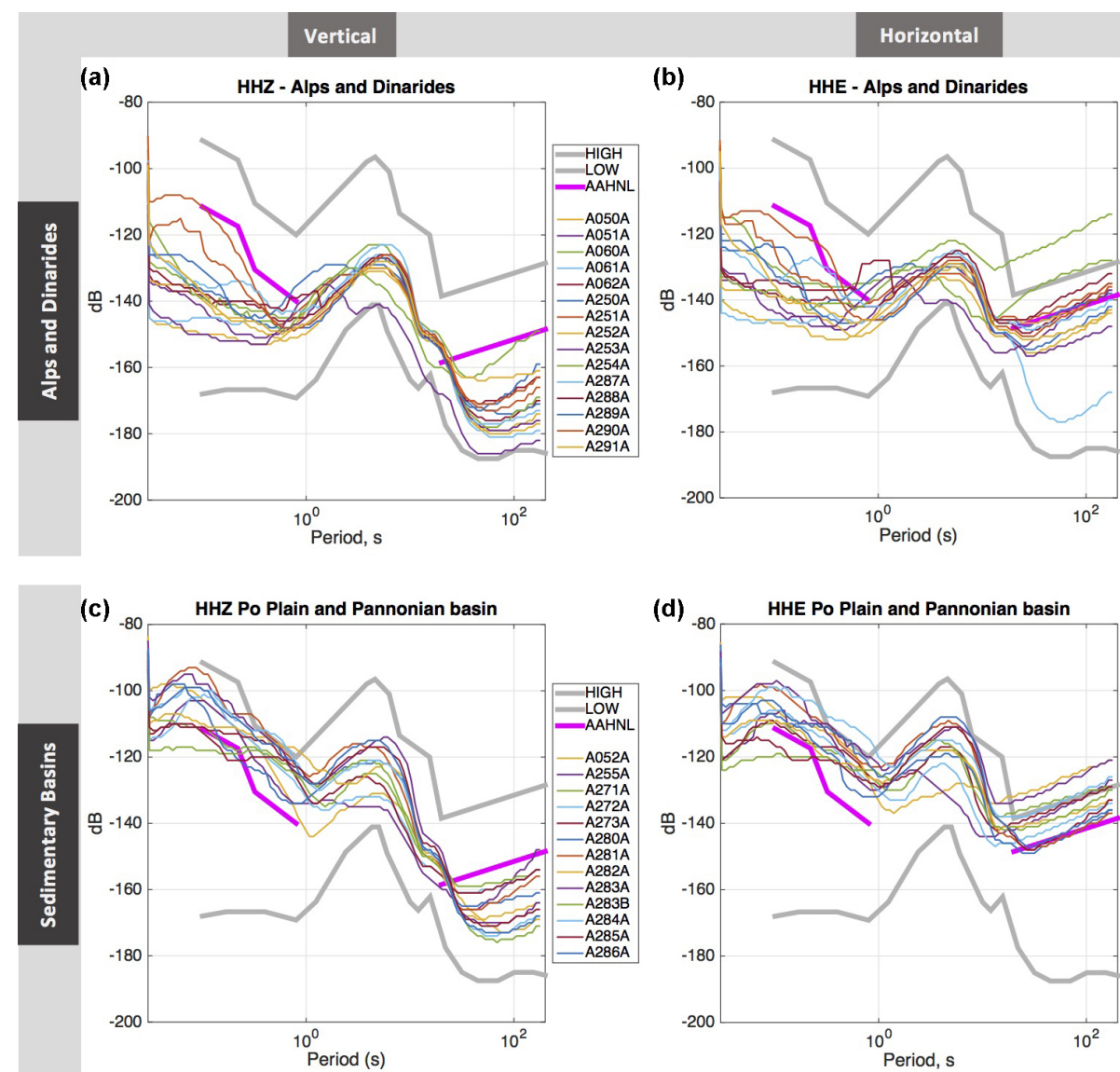

Figure 4. Median curves of the power spectral densities for the operating Swiss-AlpArray stations during the period from September 2015 to June 2016 divided in regions of installation (basins and mountains). Each line represents a single station. The light grey lines correspond to the NHNM and NLNM models, and the magenta thick line is the AlpArray noise level requirement. (a) Vertical component and (b) eastwest horizontal component of the stations in the Alps and Dinarides. (c) Vertical component and (d) east-west horizontal component of the stations in the Po Plain and Pannonian basin. The A287A and the A252A are not strictly in the Alps and Dinarides but in the hilly parts of the Po Plain and Pannonian basin, respectively.

AlpArray noise level) for all the sites; the horizontal components show a noise level ca. 20-30 dB higher than the vertical (Fig. 4b, d). The latter are highly influenced by atmospheric pressure changes and wind (e.g. Webb 2002), by building warping primarily due to temperature changes, and by the sensor-to-ground coupling. The long-period records from installations on soft sediments can also suffer from changes in soil properties due to temperature variations and water content (Wolin et al., 2015). We cannot relate the long-period horizontal noise at stations to a specific housing type or sensor shelter but we notice, as expected, a strong improvement of the long-period components when thermal isolation is installed during site tests.

The sites on rock (in the mountains) show very good performances over the whole broadband range, on average $\sim 20-30 \mathrm{~dB}$ below the AlpArray targets (Fig. 4a, b). Longperiod horizontal components show a noise level always 20$30 \mathrm{~dB}$ higher than the vertical component (that is $\sim 30-50 \mathrm{~dB}$ below the NHNM), fairly well satisfying the project require- ments. Two stations, A060A and A254A, show long period horizontal noise higher than the NHNM, due to site condition (free-field, nearby a tree) and limited data availability (less than one month for A254A) respectively. These sites are quite stable in terms of noise level (some examples in Fig. 5) with no strong seasonal or diurnal variations $(<10-15 \mathrm{~dB})$. Our best two sites are the A061A (Figs. 3a and 5a) located in a tunnel with very stable conditions with regards to temperature and pressure in a remote area in the Swiss-Alps, and A050A located in a vault (Figs. $3 \mathrm{~b}$ and $5 \mathrm{~b}$ ) in a remote forest in Bosnia and Herzegovina. All components of both stations meet or exceed noise performance for good permanent network vaults. In some stations we record remarkable diurnal effects. For example, in the site A291A (Fig. 5d) in the Dolomites with the sensor directly placed on rock in a twostory house nearby a henhouse and a small street, the PSD at short periods $(0.05$ and $0.2 \mathrm{~s})$ clearly shows the higher noise level produced by the animals and by the few cars passing by during the day. The effect of cars is also visible in the long 

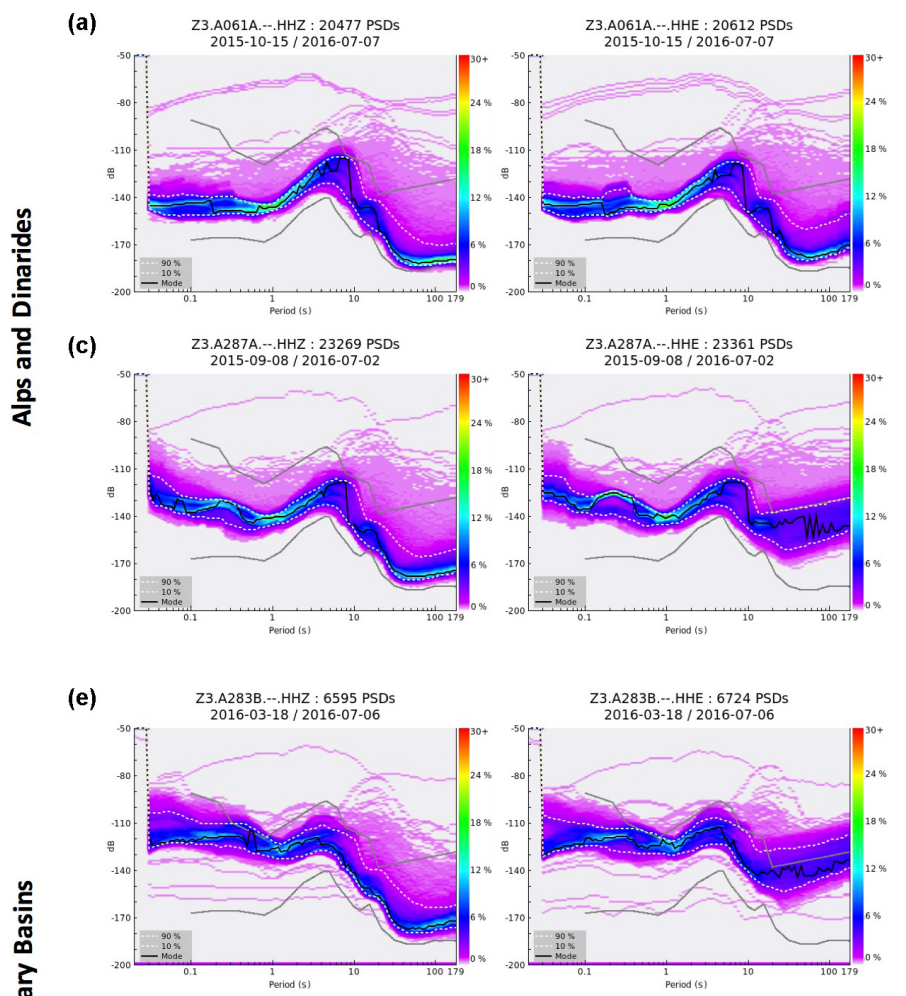

(g)
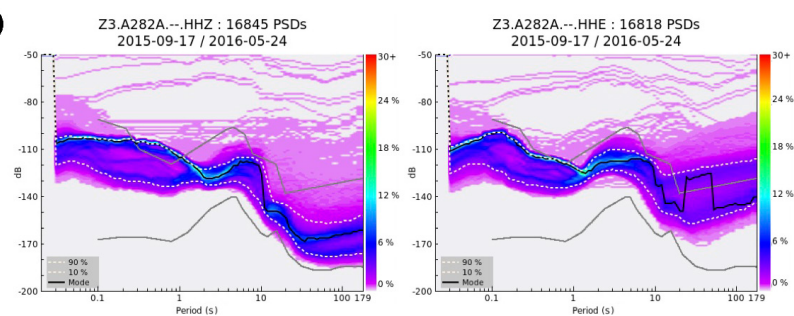

(b)

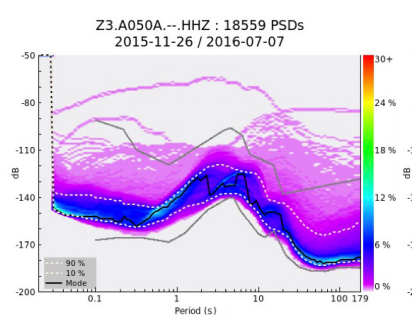

(d)
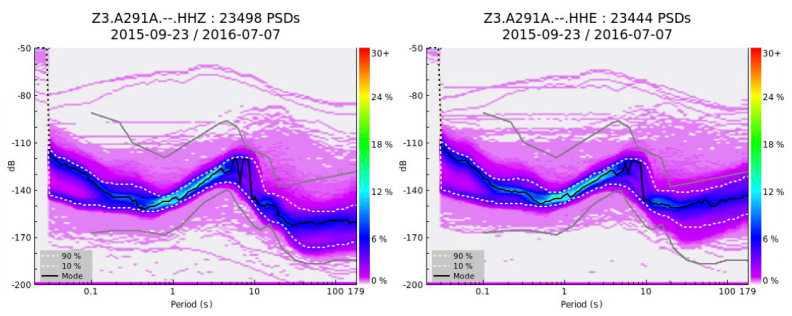

(f)
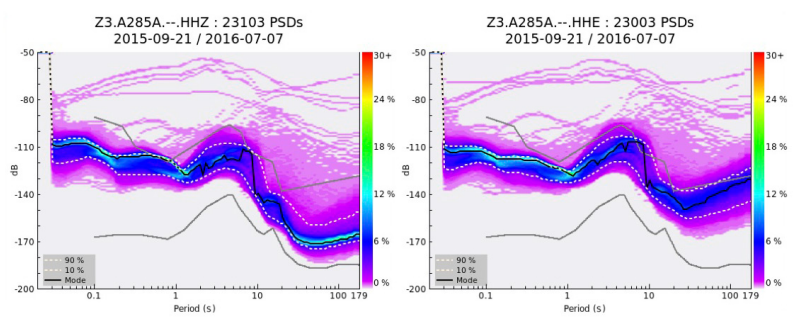

(h)
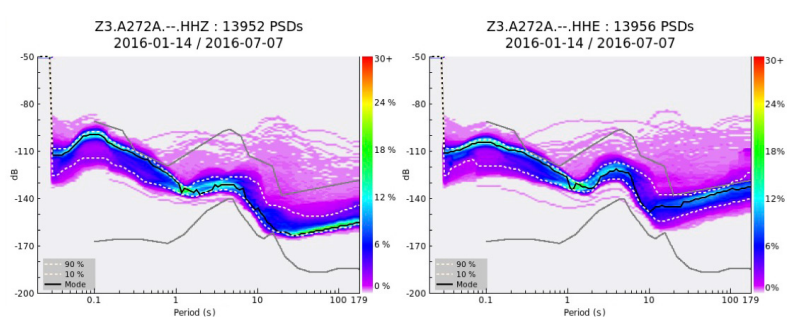

Figure 5. PDF of vertical and E-W components for the site A061A (a), A050A (b), A287A (c), A291A (d), A283B (e), A285A (f). A282A (g), A272A (h). Data is from the entire operational period of each station: from the installation (Table 1) to the beginning of July 2016, with the exception of A282A for which the data is shown until the end of May 2016. The first four sites are located in the Alps and Dinarides while the last four are in the Po Plain and the Pannonian basin. All the stations are equipped with STS-2 sensors with the exception of A272A where a Trillium Compact $120 \mathrm{~s}$ is installed. For a description see Sect. 4.

period noise. Despite these effects, the site fulfils the AASN noise requirement. An unexpected very quiet site, A287A, is located at the southernmost Alpine hills at the border with the Po Plain (Figs. 3c and 5c). Despite begin surrounded by vineyards, the short period and the vertical long-period noise are comparable with that of a permanent station in the same area (Fig. 6a). The horizontal components are, however, quite influenced by the shelter tilt.

Acceptable noise levels in sites located in densely populated basins are quite rare. It is well known that in the Po plain the seismic ambient noise is particularly strong (Marzorati and Bindi, 2006) and difficult to avoid. The general geological setting, site-effects and man-made activities make the noise level at high frequency one of the highest recorded throughout the whole experiment. High population density, high-speed trains, highways, industries, intensive agriculture and a surface geology characterized by loose sediment, clay and sand make it almost impossible to fulfil the noise level requirements, especially at high frequency. The coupling of traffic and machinery with the ground is the dominant source of high-frequency and propagates as high-frequency surface waves, with periods $<1-2 \mathrm{~s}$, that attenuate within several kilometres from the source (e.g., Havskov and Alguacil, 2004). Similar conditions, even if slightly better, are found in the Pannonian and in the Zagreb basins. Therefore, most of our stations in sedimentary basins, with the notable exception of the long-period vertical components, do not meet the AlpArray noise requirements but they also do not exceed the NHNM level (Fig. 4c, d).

From qualitative comparison of our noise levels (Fig. 4c, d) to those at INGV permanent broadband stations in the Po Plain (Fig. 6b, c), we can conclude that our station setup gen- 

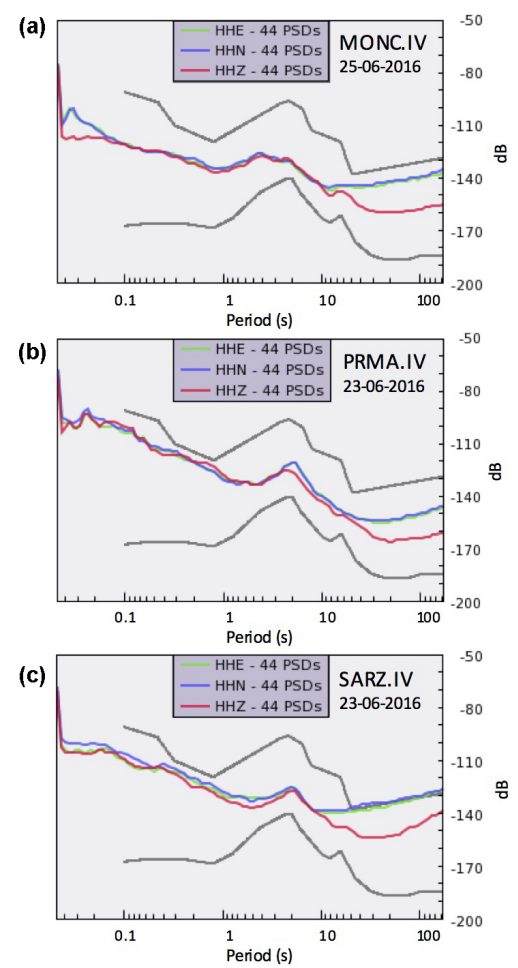

Figure 6. Median curves of the power spectral densities of the three components for three operating INGV permanent stations in the Po Plain basin (courtesy of CNT-INGV, Rome). (a) MONC is equipped with a Trillium $40 \mathrm{~s}$; (b) PRMA with a Trillium $120 \mathrm{~s}$ and (c) SARZ with a Trillium $40 \mathrm{~s}$. The stations location is marked in Fig. 1.

erally performs as well as the nearby permanent installation for short periods, and even better for long periods (especially on the vertical component). When comparing the noise levels among these stations, however, it is important to note that sensor types and installations are not identical.

Stations A283B and A285A (Fig. 5e, f) at fairly "remote" sites in the Po Plain have a quite satisfactory noise level, especially at short periods (the long-period horizontal components are high due to building tilting). As a general characteristic we note that many of the sites show a peak of noise between 0.2 and $1.5 \mathrm{~s}$ and a remarkable diurnal variation of noise sources. This is particularly true for site A282A where a noisy industrial plant disturbs the area for kilometres around causing significant huge diurnal variation.

The deployment of STS-2 as the standard seismometer for our stations facilitates collection of excellent long-period data even with temporary sites. The STS-2 has lower noise levels at long periods than many other broadband sensors (Wielandt and Streckeisen, 1982), still true today. This is clearly seen when we compare the vertical long-period noise of a STS-2 (Fig. 5a-g) with a Nanometrics Trillium Compact $120 \mathrm{~s}$ (Fig. 5h), where the improvement is typically about $\sim 20-25 \mathrm{~dB}$. For the Trillium Compact, we measure sen- sor noise, whereas for the STS-2, we typically measure site noise.

\subsection{Data completeness and data transmission}

With communication systems installed at each station, we are able to recover in real-time or quasi-real-time ca. $97 \%$ of the data. The data at 100 sps and state of health $(\mathrm{SOH})$ are continuously acquired (and also immediately archived) by the SED seismic network. 3-4 GB per month of data traffic in a usual mobile SIM-card is sufficient to guarantee the communication of all the data, also for the noisier stations in the Po Plain. The full data is also stored locally on flash drives that have the capacity to record over 6 months of data at our sampling rate. Any missing data are constantly attempted to be retrieved by a daily run python script that directly communicates with the digitizer. Still existing data gaps are definitively filled when the data are manually collected and stored in the EIDA database. In Fig. 7 we show the data availability of the 27 Swiss-AlpArray stations from real-time communication, from the installation day to the end of June 2016. Due to interruptions in station operation (power interruption for more than 1 week or serious problems with data logger and sensor) we have gaps of more than 2 weeks for the stations A060A, A272A, A283B and A288A. The advantage of having all the digitizers on-line and reachable is the possibility to monitor and react rapidly when problems are observed. We can, for example, re-centre the STS-2 masses from the office or check the remaining storage space available.

\section{Real time monitoring and integration of temporary stations in the Seismological Services}

According to the AlpArray rules, the $\mathrm{Z} 3$ network code stations are immediately available in real-time for registered seismological observatories within the AlpArray boundaries with monitoring and alerting duties (www.alparray.ethz.ch/ seismic_network/backbone/data-policy-and-citation/). The streamed data can be included in standard automated and reviewed event detection, location characterisation: in addition to helping seismic monitoring, this is a crucial benefit for the AlpArray project, as the data is being immediately used with checks being made on noise quality, timing, and metadata of the temporary stations. Any apparent malfunction can be easily detected and fixed in a reasonable time. Currently the Swiss Seismological Service (SED), the Croatian Seismological Survey, Centro Nazionale Terremoti (INGV, Italy), the Geodetic and Geophysical Research Institute of the Hungarian Academy of Sciences and the Republic Hydrometeorological Service of Republic of Srpska-Seismology Section integrate the temporary AlpArray stations in their routine services. All the seismological services currently share their permanent broadband stations data with the project. 


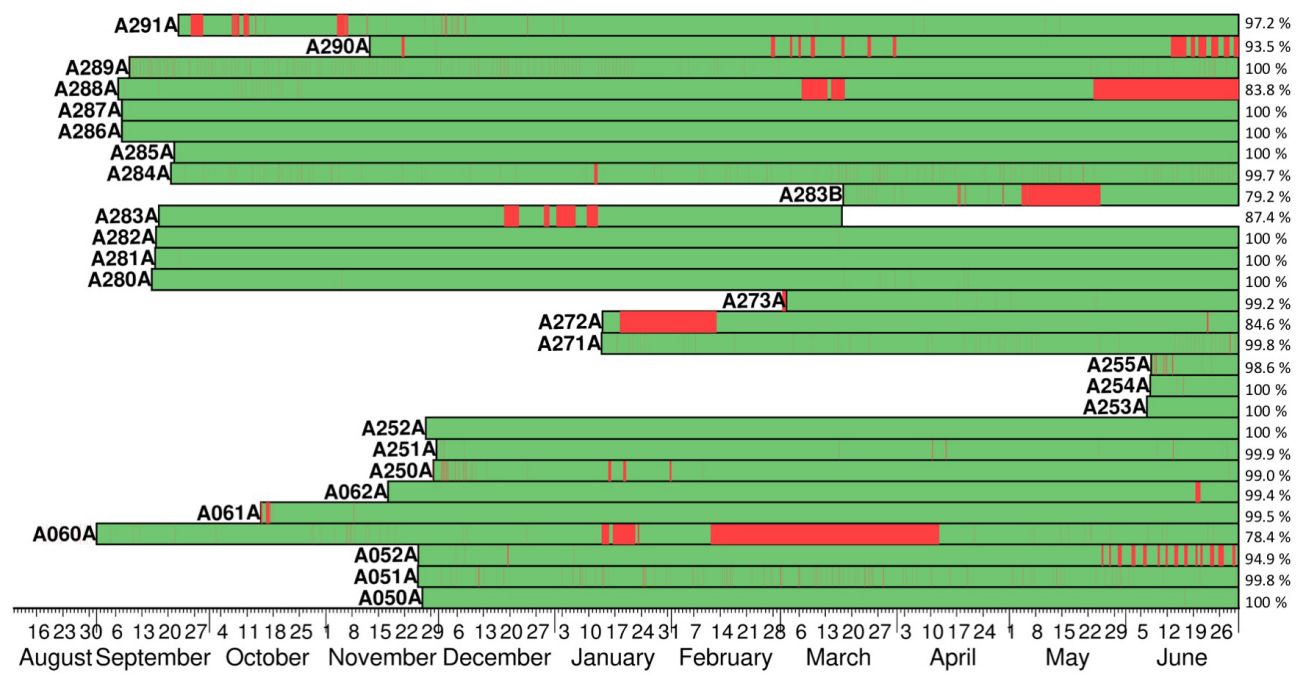

Figure 7. Data availability (green), as a function of time, of the 27 Swiss-AlpArray stations from real-time communications from the installation day to the end of June 2016. The gaps (red) are constantly filled once the data are manually collected and stored in the database. Large gaps for the stations A060A, A272A, A283A, A283B and A288A are not restorable because of station operation interruptions (mainly power interruption for more than one week or serious problems with data logger and sensor). Intermittent gaps are mainly due to connection problem (low bandwidth) and will be filled once the data are manually retrieved.

The noise performances of our stations allows the clear recording of local and teleseismic events even at the noisier stations. In Figure 8 we show the waveform from a M3.5 local earthquake that occurred near Cuneo, Italy on the 13 March 2016, and a M7.8 teleseismic event that occurred on 2 March 2016 in Sumatra. Clear phase arrivals can be identified, demonstrating that the data can be used for earthquake location and for many of the project scientific purposes. An example of the earthquake location using the AlpArray data during routine seismic service at SED is shown in Fig. 9. At least $4 \mathrm{Z3}$-stations helped to reduce the azimuthal gap in the south. Such a uniform coverage of a wide region will help to decrease detection magnitude limits and reduce earthquake location uncertainty in many areas.

In addition, the SED Seismic Network offers a real-time monitoring system to track communications, power consumption, noise changes and data completeness for all the temporary AlpArray stations. Moreover, the regular calculation of the PSD curves allow us to monitor the noise situation at each site and promptly decide and intervene whenever is needed.

\section{Conclusion}

The principles and procedures described in this paper allow the collection of top quality seismological data in a densely populated region with challenging lithological subsurface conditions. This dataset will provide the means to address by state-of-art seismic methods important and exciting scientific questions on current geodynamics and the evolution of the Alps and to improve the seismic hazard assessment in the region.

Our temporary stations performance, in general, meets the AlpArray Seismic Network quality requirements in terms of noise level (i.e. $20 \mathrm{~dB}$ lower than the NHNM for vertical components and $10 \mathrm{~dB}$ lower of NHNM for horizontal component), with the exception of highfrequencies $(>1 \mathrm{~Hz})$ for stations in the sedimentary basins. All 27 stations we deployed are characterized by a noise levels lower than the maximum NHNM. Sensors in the Alps and Dinaridies show a noise level $\sim 10-20 \mathrm{~dB}$ lower than the AlpArray requirement in the whole frequency range, while unavoidable cultural noise in the sedimentary basins (Po plain and Pannonian basin) reduces station performances by at least $20 \mathrm{~dB}$. In general, the challenges of installing temporary stations in deep sedimentary basins was met quite successfully as our temporary stations perform as well as permanent installations there. Noise characteristics of the whole AASN will be the subject of a future and detailed study that is beyond the scope of this work.

\section{Data availability}

Waveform data from all AlpArray Seismic Network (AASN) stations is available through EIDA (http://www.orfeus-eu. org/eida/). On this platform, all AASN stations are consolidated under a Virtual Network code "_ALPARRAY”. All temporary stations in the AASN use the Z3 network code (AlpArray Seismic Network, 2015); an exception is made for seven temporary CR stations included in the backbone and deployed within the VELEBIT project by the Croatian Sci- 

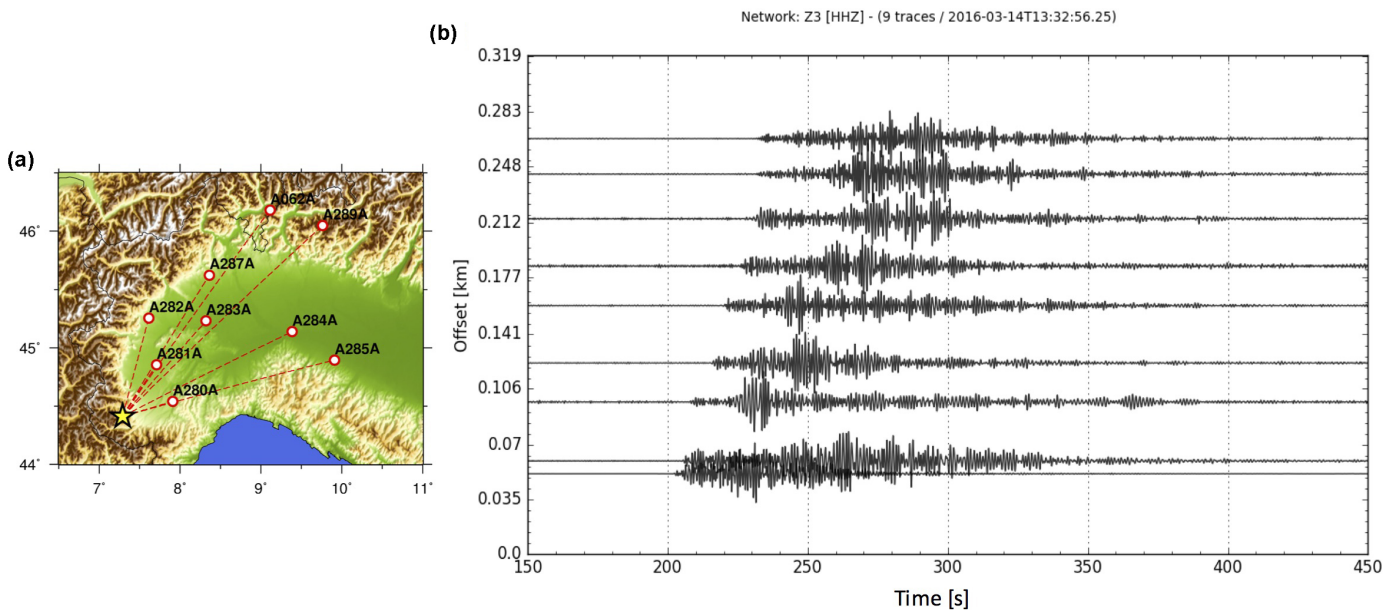

(d)
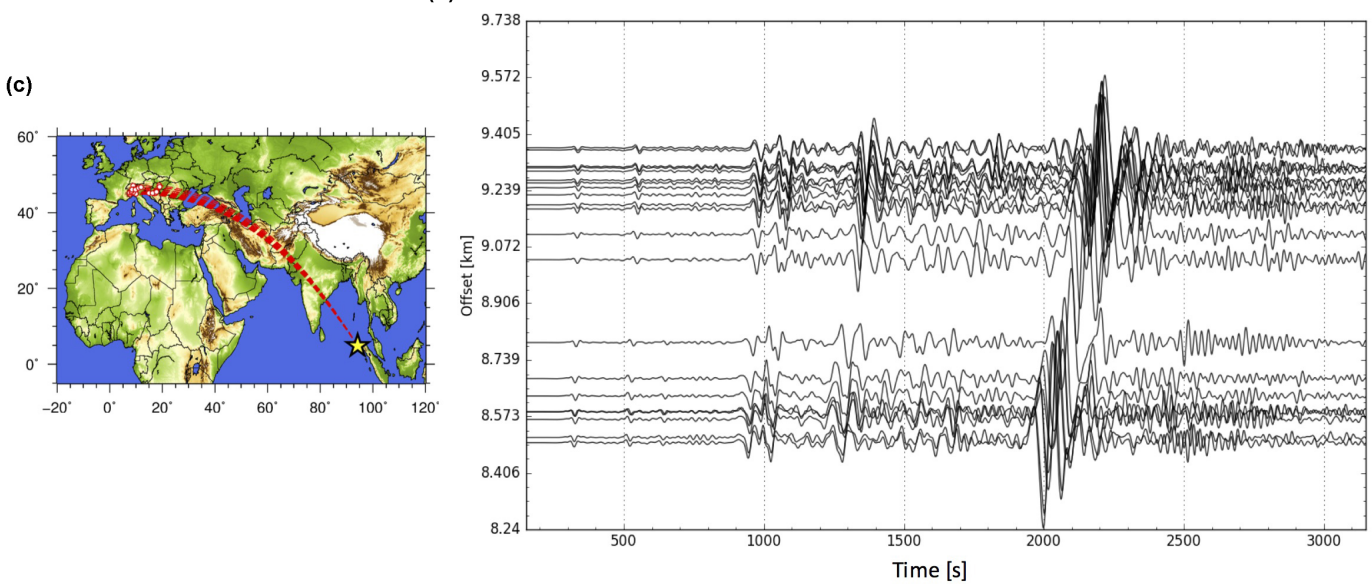

Figure 8. Examples of waveforms recorded by the Swiss-AlpArray temporary stations. (a) Location of the M3.5 local earthquake occurred the 14-03-2016 and of the recording station (b) associated waveform filtered using a high-pass filter with corner frequency of $0.4 \mathrm{~Hz}$; (c) Location of M7.8 teleseismic event occurred the 2 March 2016 in Sumatra and (d) recorded signals, bandpass filtered with corner frequencies of 0.008 and $0.05 \mathrm{~Hz}$.

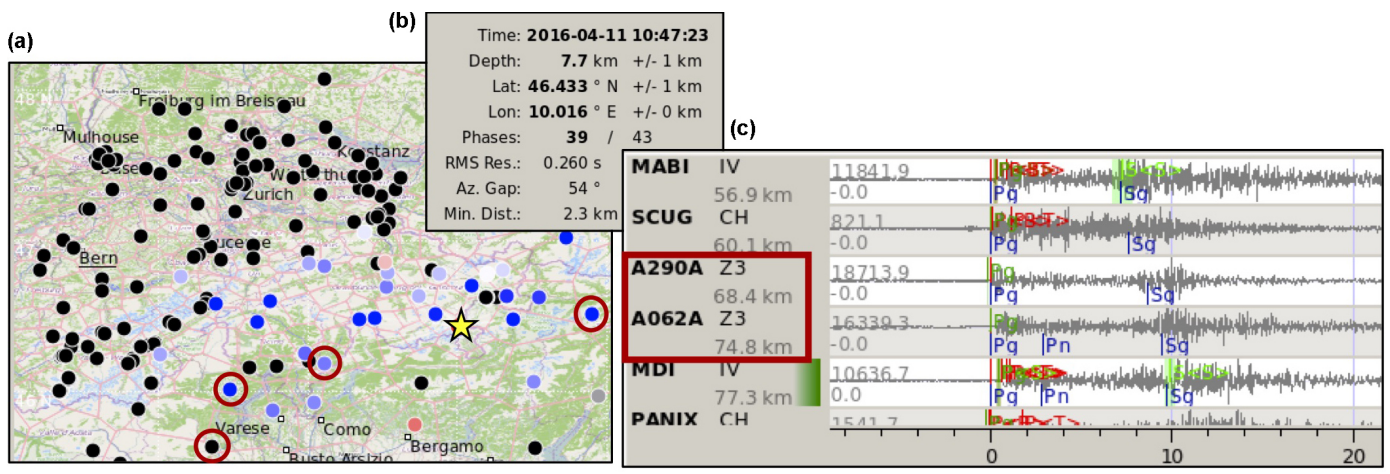

Figure 9. Location solution of the Poschiavo (Switzerland) M3.2 event occurred on 11 April 2016 calculated at the Swiss Seismological Service (SED-ETHZ). At least four AlpArray stations are used to improve the location and to fill the south gap. Green lines are manually detected Pg and Sg picks. The location procedures are performed using SeisComp3 software. 
ence Foundation. The existing permanent network stations that are part of the AASN use their parent network codes, and are typically openly available. $\mathrm{Z} 3$ data is currently restricted to the Core Group of the AASN, and is not openly accessible. Visit http://www.alparray.ethz.ch/seismic_network/ backbone/data-access/ for further information on data access and http://www.alparray.ethz.ch/seismic_network/backbone/ data-policy-and-citation/ for information of data policy. Information about the AlpArray project is available and constantly updated at www.alparray.ethz.ch.

In the AASN, the permanent stations are contributed via the following networks codes: BW, CH (Swiss Seismological Service (SED) at ETH Zurich, 1983), CR, CZ (Institute of Geophysics, Academy of Sciences of the Czech Republic, 1973), FR (RESIF, 1995), CR, HU, G (Institut de Physique du Globe de Paris (IPGP), \& Ecole et Observatoire des Sciences de la Terre de Strasbourg (EOST), 1982), GE (GEOFON Data Centre, 1993), GR, GU (University of Genova, 1967), HS, HU (Kövesligethy Radó Seismological Observatory, 1992), IU (Albuquerque Seismological Laboratory (ASL)/USGS, 1988), IV (INGV Seismological Data Centre, 1997), MN (MedNet project partner institutions, 1988), NI (OGS (Istituto Nazionale di Oceanografia e di Geofisica Sperimentale) and University of Trieste, 2002), OE, OX (OGS (Istituto Nazionale di Oceanografia e di Geofisica Sperimentale), 2016), PL, RD, RF (University of Trieste, 1993), SI, SK, SL, ST (Geological Survey-Provincia Autonoma di Trento, 1981), SX, TH.

Team list. Swiss-AlpArray Field Team: Irene Molinari (Institute of Geophysics, Department of Earth Sciences, ETH Zürich, 8092 Zürich, Switzerland), Eduard Kissling (Institute of Geophysics, Department of Earth Sciences, ETH Zürich, 8092 Zürich, Switzerland), Domenico Giardini (Institute of Geophysics, Department of Earth Sciences, ETH Zürich, 8092 Zürich, Switzerland), György Hetényi Institute of Earth Sciences, University of Lausanne, 1015 Lausanne, Switzerland), John Clinton (Swiss Seismological Service, ETH Zürich, 8092 Zürich, Switzerland), Stefan Wiemer (Swiss Seismological Service, ETH Zürich, 8092 Zürich, Switzerland), Florian Haslinger (Swiss Seismological Service, ETH Zürich, 8092 Zürich, Switzerland), Matteo Bagagli (Institute of Geophysics, Department of Earth Sciences, ETH Zürich, 8092 Zürich, Switzerland), Erika D. Erlanger (Institute of Geophysics, Department of Earth Sciences, ETH Zürich, 8092 Zürich, Switzerland), Pascal Graf (Swiss Seismological Service, ETH Zürich, 8092 Zürich, Switzerland), Robin Hansemann (Swiss Seismological Service, ETH Zürich, 8092 Zürich, Switzerland), Marcus Hermann (Swiss Seismological Service, ETH Zürich, 8092 Zürich, Switzerland), Paula Koelemeijer (Institute of Geophysics, Department of Earth Sciences, ETH Zürich, 8092 Zürich, Switzerland), Anne Obermann (Swiss Seismological Service, ETH Zürich, 8092 Zürich, Switzerland), Roman Racine (Swiss Seismological Service, ETH Zürich, 8092, Zürich, Switzerland), Korbinian Sager (Institute of Geophysics, Department of Earth Sciences, ETH Zürich, 8092 Zürich, Switzerland), Julia Singer (Institute of Geophysics, Department of Earth Sciences, ETH Zürich, 8092 Zürich, Switzer- land), Robert Tanner (Swiss Seismological Service, ETH Zürich, 8092 Zürich, Switzerland), Sascha Winterberg (Institute of Geophysics, Department of Earth Sciences, ETH Zürich, 8092 Zürich, Switzerland), Andre Blanchard (Institute of Geophysics, Department of Earth Sciences, ETH Zürich, 8092 Zürich, Switzerland), Leonardo Colavitti (Institute of Earth Sciences, University of Lausanne, 1015 Lausanne, Switzerland), Tommaso Giardini (Swiss Seismological Service, ETH Zürich, 8092 Zürich, Switzerland), Josip Stipčević (Department of Geophysics, Faculty of Science, University of Zagreb, 10000 Zagreb, Croatia), Iva Dasović (Department of Geophysics, Faculty of Science, University of Zagreb, 10000 Zagreb, Croatia), Marijan Herak (Department of Geophysics, Faculty of Science, University of Zagreb, 10000 Zagreb, Croatia), Davorka Herak (Department of Geophysics, Faculty of Science, University of Zagreb, 10000 Zagreb, Croatia), Vesna Šipka (Republic Hydrometeorological Service of Republic of Srpska, 7800 Banja Luka, Bosnia and Herzegovina), Dejan Jarić (Republic Hydrometeorological Service of Republic of Srpska, 7800 Banja Luka, Bosnia and Herzegovina), Shasa Šikman (Republic Hydrometeorological Service of Republic of Srpska, 7800 Banja Luka, Bosnia and Herzegovina), Zoltán Wéber (Kövesligethy Radó Seismological Observatory, Geodetic and Geophysical Research Institute of the Hungarian Academy of Sciences, 1112 Budapest, Hungary), Zoltán Gráczer (Kövesligethy Radó Seismological Observatory, Geodetic and Geophysical Research Institute of the Hungarian Academy of Sciences, 1112 Budapest, Hungary), Stefano Solarino (Istituto Nazionale di Geofisica e Vulcanologia, 00143 Roma, Italy).

Author contributions. Irene Molinari coordinates, organizes and participates all the site scouting, station deployments, data quality control and prepared the manuscript with contributions from all co-authors. John Clinton manages data flow and quality control. Edi Kissling is the principal investigator of Swiss-AlpArray and AlpArray and supervises the project. György Hetényi participated in the initial phase of the project setup and station deployment, and manages the AlpArray Seismic Network. Domenico Giardini initiated the AlpArray project. Josip Stipčević, Iva Dasović and Marijan Herak scouted for sites and deployed the six seismic stations in Croatia, Vesna Šipka scouted and deployed the three seismic stations in Bosnia and Herzegovina. Zoltán Wéber and Zoltán Gráczer scouted and deployed the three seismic stations in Hungary. S. Solarino participated in the scouting and installations of 5 sites in Italy. The Swiss-AlpArray Field Team participates in the scouting, installation and maintenance of all Swiss-AlpArray stations. The AlpArray Working Group worked out the network layout, quality guidelines and standards for the seismic data exchange.

Acknowledgements. The authors are grateful to the AlpArray Seismic Network Team (http://www.alparray.ethz.ch/seismic_ network/backbone/management/) who builds and maintains the entire AlpArray Seismic Network. AlpArray Switzerland is funded by the Swiss-AlpArray SINERGIA project CRSII2_154434/1 by Swiss National Science Foundation (SNSF). The Croatian part of the site planning and scouting has been done in cooperation with the VELEBIT project funded by the Croatian Science Foundation, grant HRZZ IP-2014-09-9666. We thank the SED Seismic Network 
Group and the SED Electronic Lab (ELAB) for their constant help, support and advices to all the field activities and data management procedures. We are grateful to INGV for sharing the PSD images for the three permanent stations in Fig. 6. Figures have been prepared using the Generic Mapping tools (Wessel and Smith, 1998) and Obspy (Krischer et al., 2015).

Edited by: D. Pesaresi

Reviewed by: F. J. Tilmann and one anonymous referee

\section{References}

Albuquerque Seismological Laboratory (ASL)/USGS: Global Seismograph Network (GSN - IRIS/USGS), International Federation of Digital Seismograph Networks, Other/Seismic Network, doi:10.7914/SN/IU, 1988.

AlpArray Seismic Network: AlpArray Seismic Network (AASN) temporary component, AlpArray Working Group, Other/Seismic Network, doi:10.12686/alparray/z3_2015, 2015.

Cooley, J. W. and Tukey J. W.: An algorithm for the machine calculation of complex Fourier series, Math. Comput., 19, 297-301, 1965.

Díaz J., Villaseñor, A., Morales, J., Pazos, A., Cordoba,D., Pulgar, J., García-Lobón, J. L., Harnafi, M., Carbonell, R., Gallart, J., and TopoIberia Seismic Working Group: Background Noise characteristics at the IberArray broadband seismic network, B. Seismol. Soc. Am., 12, 618-628, doi:10.1785/0120090085, 2010.

Ekström, G. and Busby, R. W.: Measurements of Seismometer Orientation at USArray Transportable Array and backbone stations, Seismol. Res. Lett., 79, 554-561, doi:10.1785/gssrl.79.4.554, 2008.

Forbriger, T.: Recommendations for seismometer deployment and shielding, in: New Manual of Seismological Observatory Practice 2 (NMSOP-2), edited by: Bormann, P., Deutsches GeoForschungsZentrum GFZ, Potsdam, doi:10.2312/GFZ.NMSOP2_IS_5.4, 1-10, 2012.

GEOFON Data Centre: GEOFON Seismic Network. Deutsches GeoForschungsZentrum GFZ, doi:10.14470/TR560404, 1993.

Geological Survey-Provincia Autonoma di Trento: Trentino Seismic Network, International Federation of Digital Seismograph Networks, Other/Seismic Network, doi:10.7914/SN/ST, 1981.

Havskov, J. and Alguacil, G.: Instrumentation in Earthquake Seismology, in Modern Approaches in Geophysics Series, Vol. 22, Springer, Dordrecht, the Netherlands, 328 pp., 2004.

Hutt, C. R. and Ringler, A.: A summary of STS-2 low-noise installation methods tested at the USGS Albuquerque Seismological Laboratory, http://bnordgren.org/seismo/ STS-2InstallationMethods.pdf (last access: June 2016), 2009.

Krischer, L., Megies, T., Barsch, R., Beyreuther, M., Lecocq, T., Caudron, C., and Wassermann, J.: ObsPy: a bridge for seismology into the scientific Python ecosystem, Computational Science \& Discovery, 8, 014003, doi:10.1088/1749-4699/8/1/014003, 2015.

Kövesligethy Radó Seismological Observatory (Geodetic and Geophysical Institute, R. C. for A. and E. S., Hungarian Academy of Sciences (MTA CSFK GGI KRSZO)), Hungarian National Seismological Network. Deutsches GeoForschungsZentrum GFZ, doi:10.14470/UH028726, 1992.
INGV Seismological Data Centre: Rete Sismica Nazionale (RSN), Istituto Nazionale di Geofisica e Vulcanologia (INGV), Italy, doi:10.13127/SD/X0FXnH7QfY, 1997.

Institute of Geophysics, Academy of Sciences of the Czech Republic: Czech Regional Seismic Network, International Federation of Digital Seismograph Networks, Other/Seismic Network, doi:10.7914/SN/CZ, 1973.

Institut de Physique du Globe de Paris (IPGP), \& Ecole et Observatoire des Sciences de la Terre de Strasbourg (EOST): GEOSCOPE, French Global Network of broad band seismic stations, Institut de Physique du Globe de Paris (IPGP), doi:10.18715/GEOSCOPE.G, 1982.

Langlais, M., Vial, B., and Coutant, O.: Improvement of broadband seismic station installations at the Observatoire de Grenoble (OSUG) seismic network, Adv. Geosci., 34, 9-14, doi:10.5194/adgeo-34-9-2013, 2013.

Marzorati, S. and Bindi, D.: Ambient noise levels in north central Italy, Geochem. Geophy. Geosy., 7, Q09010, doi:10.1029/2006GC001256, 2006.

McNamara, D. E. and Boaz, R. I.: Seismic Noise Analysis System, Power Spectral Density Probability Density Function: StandAlone Software Package, United States Geological Survey Open File Report, No. 2005-1438, 30 pp., 2005.

McNamara, D. E. and Buland, R. P.: Ambient Noise Levels in the Continental United States, B. Seism. Soc. Am., 94, 1517-1527, 2004.

MedNet project partner institutions: Mediterranean Very Broadband Seismographic Network (MedNet), Istituto Nazionale di Geofisica e Vulcanologia (INGV), Italy, doi:10.13127/SD/fBBBtDtd6q, 1988.

OGS (Istituto Nazionale di Oceanografia e di Geofisica Sperimentale): North-East Italy Seismic Network, International Federation of Digital Seismograph Networks, Other/Seismic Network, doi:10.7914/SN/OX, 2016.

OGS (Istituto Nazionale di Oceanografia e di Geofisica Sperimentale) and University of Trieste: North-East Italy Broadband Network, International Federation of Digital Seismograph Networks, Other/Seismic Network, doi:10.7914/SN/NI, 2002.

Peterson, J.: Observations and modeling of seismic background noise, USGS Open-File report 93-322, 1993.

RESIF: RESIF-RLBP French Broad-band network, RESIF-RAP strong motion network and other seismic stations in metropolitan France, RESIF - Réseau sismologique \& géodésique français, doi:10.15778/RESIF.FR, 1995.

Swiss Seismological Service (SED) at ETH Zurich: National Seismic Networks of Switzerland, ETH Zürich, doi:10.12686/sed/networks/ch, 1983.

University of Genova: Regional Seismic Network of North Western Italy, International Federation of Digital Seismograph Networks, Other/Seismic Network, doi:10.7914/SN/GU, 1967.

University of Trieste: Friuli Venezia Giulia Accelerometric Network, International Federation of Digital Seismograph Networks, Other/Seismic Network, doi:10.7914/SN/RF, 1993.

Wessel, P. and Smith, W. H. F.: New, improved version of the Generic Mapping Tools released, Eos T. AGU, Volume 79, p. $579,1998$.

Webb, S. C.: Seismic Noise on Land and on the Sea Floor, in Int. Hand-book on Earthquake and Engineering Seismology, Part A, Chapter 19, 305-318, edited by: Lee, W. H. K., Kanamori, H., 
Jennings, P. C., and Kisslinger, C., Academic Press, Amsterdam, 2002.

Wielandt, E. and Streckeisen, G.: The leaf-spring seismometer: Design and performance, B. Seismol. Soc. Am., 72, 2349-2367, 1982.
Wolin, E., van der Lee, S., Bollmann, T. A., Wiens, D. A., Revenaugh, J., Darbyshire, F. A., Frederiksen, A. W., Stein, S., and Wysession, M. E.: Seasonal and Diurnal Variations in LongPeriod Noise at SPREE Stations: The Influence of Soil Characteristics on Shallow Stations Performance, B. Seismol. Soc. Am., 105, 2433-2452, doi:10.1785/0120150046, 2015. 